\title{
Article
}

\section{Mechanical properties investigations of the plasma sprayed coatings based on alumina powder}

\author{
Joanna Spyra ${ }^{1}$, Monika Michalak ${ }^{1}$, Aneta Niemiec ${ }^{1}$ and Leszek Latka ${ }^{1, *}(\mathbb{1})$ \\ 1 Faculty of Mechanical Engineering, Wrocław University of Science and Technology, Poland \\ Joanna Spyra, 237447@student.pwr.edu.pl (J.S.); monika.michalak@pwr.edu.pl (M.M.); \\ aneta.niemiec@pwr.edu.pl (A.N.) \\ * Correspondence: leszek.latka@pwr.edu.pl (L.Ł.)
}

Received: 23.04.2020; Accepted: 31.05.2020;

\begin{abstract}
In this paper $\mathrm{Al}_{2} \mathrm{O}_{3}+13 \mathrm{wt} \% \mathrm{TiO}_{2}$ ceramic coatings manufactured by Atmospheric Plasma Spraying (APS) have been investigated. The commercial feedstock materials, Metco 6221 (top coat) and Amdry 4535 (bond coat) have been deposited on stainless steel coupons. The main goal of researches was to determine the influence of critical plasma spray parameters (CPSP) on structure and properties of the coatings. In present studies, the electrical power was a variable parameter. Coatings have been characterized in the terms of microstructure, topography, bond strength adhesion, fracture toughness and wear resistance. As a result, it was observed, that coatings sprayed with higher value of the electrical power exhibit higher mechanical properties due to better cohesion as well as higher melting degree.
\end{abstract}

Keywords: thermal spraying; plasma spraying; alumina coatings; mechanical properties; microstructure

\section{Introduction}

Thermal spraying technologies are commonly used in order to improve the surfaces of the machine elements. Among many methods, Atmospheric Plasma Spraying (APS) is one of the most widely used. Many types of metals, cermet and ceramics are used as a feedstock material [1,2]. In this group one of the most frequently used are $\mathrm{Al}_{2} \mathrm{O}_{3}$ and $\mathrm{TiO}_{2}$. Powders which have agglomerated and sintered morphology are very interesting from an application point of view [3,4]. Coatings based on pure alumina are used when the wear resistance and corrosion against chemical agents is required [5]. The addition of $\mathrm{TiO}_{2}$ decreases the melting temperature of such compound, which results in lower porosity of manufactured coatings. These coatings are also characterized by higher fracture toughness, in comparison to pure alumina ones [6]. Generally, the most frequent mixtures are as follow: $\mathrm{Al}_{2} \mathrm{O}_{3}+3 \mathrm{wt} \% \mathrm{TiO}_{2}, \mathrm{Al}_{2} \mathrm{O}_{3}+13 \mathrm{wt} \% \mathrm{TiO}_{2}$ and $\mathrm{Al}_{2} \mathrm{O}_{3}+40 \mathrm{wt} \% \mathrm{TiO}_{2}$ [1,7]. Applications of such coatings is very wide, include e.g. paper and textile industry, automotive and aviation branches and many others [8,9]. Coatings based on $\mathrm{Al}_{2} \mathrm{O}_{3}+13 \mathrm{wt} \% \mathrm{TiO}_{2}$ show the best properties, such as: good wear resistance, low value of the friction coefficient, relatively high hardness and low porosity [10,11].

In the paper the influence of the critical plasma spray parameters (CPSP) [12] on microstructure and mechanical properties of the sprayed coatings was described.

\section{Materials and Methods}

The feedstock material, which was used in the researches, was commercially available powder Metco 6221 (Oerlikon Metco, Germany) with chemical composition $\mathrm{Al}_{2} \mathrm{O}_{3}+13 \mathrm{wt} \% \mathrm{TiO}_{2}$. The powder particles had a spherical morphology and were produced in agglomerated and sintered form. The diameter of the particles was in the range $-45+15$ microns. The measured main volume to surface diameter $(d v s)$ was equal to $33 \mu \mathrm{m}$.

In order to improve adhesion of the ceramic coatings to the substrate, the bond coat was used. The feedstock material was a metallic powder of the mixture nickel and chromium $(\mathrm{Ni}+20 \mathrm{wt} \% \mathrm{Cr})$. It was also a commercially available powder Amdry 4535 (Oerlikon Metco, Germany). This powder has a spherical morphology and the diameter of the particles was in the range $-53+11$ microns.

Coatings deposition have been realized with use of the plasma torch, SG-100 (Praxair, IN, USA), which was mounted on the arm of the industrial robot Fanuc 2000IA. Plasma gases mixture was composed of argon 
and hydrogen. Argon was also used as a transport medium. The bond coat has been manufactured with parameters collected in table I.

Table I. Parameters of the bond coat spraying process

\begin{tabular}{cc}
\hline Spray distance, $\mathbf{~ m m}$ & 100 \\
\hline Linear torch velocity, $\mathbf{~ m m} / \mathbf{s}$ & 400 \\
\hline Electrical power, $\mathbf{k W}$ & 28 \\
\hline Powder feed rate, $\mathbf{g} / \mathbf{m i n}$ & 15 \\
\hline${\text { Plasma gases feed rate, } \mathbf{S L P M}{ }^{1}}^{1}$ & $\mathrm{Ar}=45, \mathrm{H}_{2}=5$ \\
\hline Transport gas feed rate, $\mathbf{S L P M}$ & $\mathrm{Ar}=3$ \\
\hline${ }^{1}$ Standard litter per minute &
\end{tabular}

Ceramic coatings have been sprayed with the assumption of variable values of the CPSP, calculated according to the formula:

$$
\mathrm{CPSP}=\mathrm{Pel} / \mathrm{f}_{\mathrm{ppg}}
$$

where:

Pel - electrical power, $\mathrm{kW}$;

$\mathrm{f}_{\mathrm{ppg}}-$ feed rate of the primary plasma gas, SLPM

The process parameters of the ceramic coatings manufacturing, including sample code, are collected in table II.

Table II. Sample code and parameters of the ceramic coating spraying process

\begin{tabular}{cccccc}
\hline $\begin{array}{c}\text { Sample } \\
\text { code }\end{array}$ & $\begin{array}{c}\text { Electrical } \\
\text { power, } \\
\text { kW }\end{array}$ & $\begin{array}{c}\text { CPSP } 1 \\
\text { value }\end{array}$ & $\begin{array}{c}\text { Spray } \\
\text { distance, } \\
\mathbf{m m}\end{array}$ & $\begin{array}{c}\text { Linear } \\
\text { torch velocity, } \\
\mathbf{m m} / \mathbf{s}\end{array}$ & $\begin{array}{c}\text { Powder } \\
\text { feed rate, } \\
\text { g/min }\end{array}$ \\
\hline P-622 & 28 & 622 & & & \\
P-689 & 31 & 689 & 90 & 250 & 18 \\
P-756 & 34 & 756 & & & \\
\hline
\end{tabular}

${ }^{1}$ Calculated from eq. (1)

Feed rates of the plasma gases, as well as transport one were the same for ceramic coatings and for bond coat.

Substrates were a cylinder shape with $25 \mathrm{~mm}$ in the diameter, $2 \mathrm{~mm}$ in the thickness and were made from austenitic stainless steel (X5CrNi18-10). Before spraying, the substrate surfaces were sand-blasted with corundum F40 (according to the FEPA standard) and then cleaned in the ethanol. The powders for bond coat and ceramic coating were fed radially.

Coatings topography and microstructure have been characterized using scanning electron microscope Phenom G2 Pro (Phenom World, Eindhoven, Netherlands). Based on the micrographs of the cross sections the coatings thickness and porosity were estimated. The thickness was calculated as an average value from 10 measurements in random localization. The porosity was estimated according to the ASTM E2109-01 standard using ImageJ software for digital image analysis. It was made based on 20 micrographs.

Coatings microhardness has been measured using Vickers penetrator with maximum load equal to $0.98 \mathrm{~N}$ (HV0.1) with microhardness tester HV-1000 (Sinowon, China). The measurements were carried out in accordance to the EN ISO 4516:2004 standard. On the coating's cross section 10 imprints were made for each sample.

The bond strength of the coatings was defined in accordance to the EN ISO 14916:2017-05 standard. In order to prepare the samples for this test, the cold cured glue, Distal Classic (Libella, Warsaw, Poland) was used. The average strength of the glue is equal to $50 \mathrm{MPa}$.

Fracture toughness has been estimated in accordance to the EN ISO 14577-4:2017-02 standard, based on the methodology described in [13]. For calculations of the critical stress intensity factor (Kc) the Anstis formula [14] was used:

$$
\mathrm{K}_{\mathrm{C}}=0.016 \cdot(\mathrm{E} / \mathrm{H})^{1 / 2} \cdot\left(\mathrm{P} / \mathrm{c}^{1.5}\right)
$$

where:

$\mathrm{E}$ - elastic modulus, $\mathrm{MPa}$ 
$\mathrm{H}$ - Vickers hardness, MPa

$\mathrm{P}$ - maximum loading of the indenter, $\mathrm{N}$

$\mathrm{c}$ - total cracking length, $\mathrm{m}$

Wear resistance of the sprayed coatings has been defined in accordance to the ASTM G99 standard in the ball on disc method. The T-01 device (ITeE-PIB, Radom, Poland) was used. As a counter-body, the steel ball (100Cr6) with diameter equal to $6 \mathrm{~mm}$ was used. The sliding distance was equal to $500 \mathrm{~m}$, the linear velocity was equal to $0.1 \mathrm{~m} / \mathrm{s}$. The loading of the ball was equal to $10 \mathrm{~N}$ and the radius of the sliding was equal to $5 \mathrm{~mm}$. The wear rate $\left(K_{v}\right)$ was calculated from wear formula of Lancaster [15]:

$$
\mathrm{K}_{\mathrm{v}}=\mathrm{V}_{\text {wear }} / \mathrm{F}_{\mathrm{N}} \cdot \mathrm{S} \text {, }
$$

where:

$\mathrm{V}_{\text {wear }}$ - volume lost, $\mathrm{mm}^{3}$

$\mathrm{F}_{\mathrm{N}}$ - normal load, $\mathrm{N}$

$\mathrm{S}$ - sliding distance, $\mathrm{m}$

\section{Results and discussion}

The morphology and microstructure of the sprayed coatings are shown in figure 1 and figure 2 respectively. The surface topography revealed that with the increased electrical power, the coatings were characterized by better melting of powder particles. Additionally, more regular splats, typical for this spraying method, were observed. The absence or very small amount of cracks suggests that the thermal stresses reached a low level, and thus resulted from the selection of parameters (apart from the electrical power, the distance of spraying and torch scan speed were especially important). A similar coatings' topography can be seen in [16].

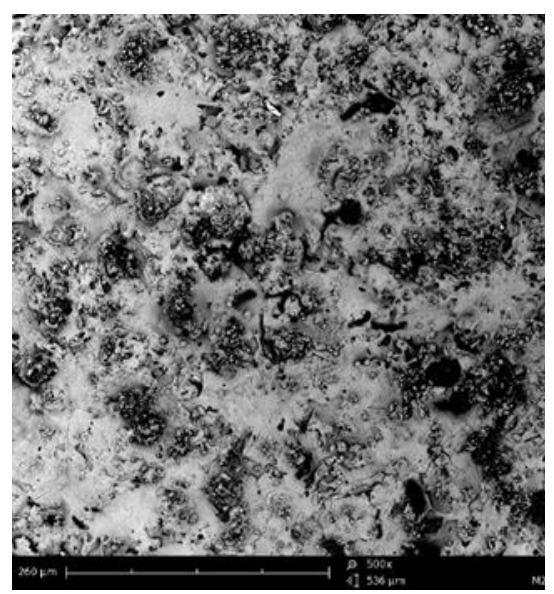

(a)

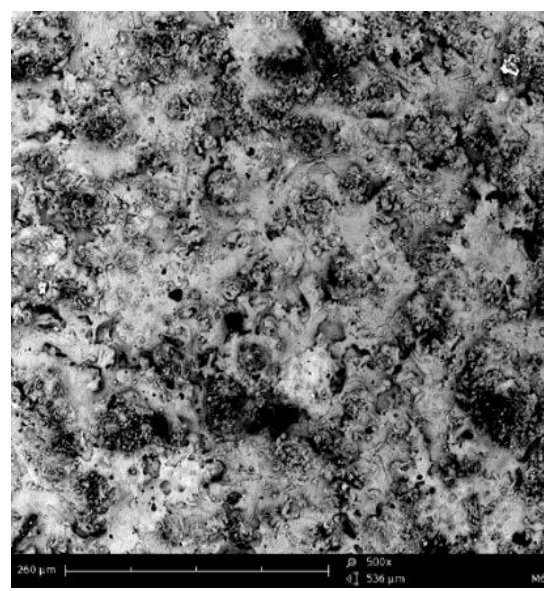

(b)

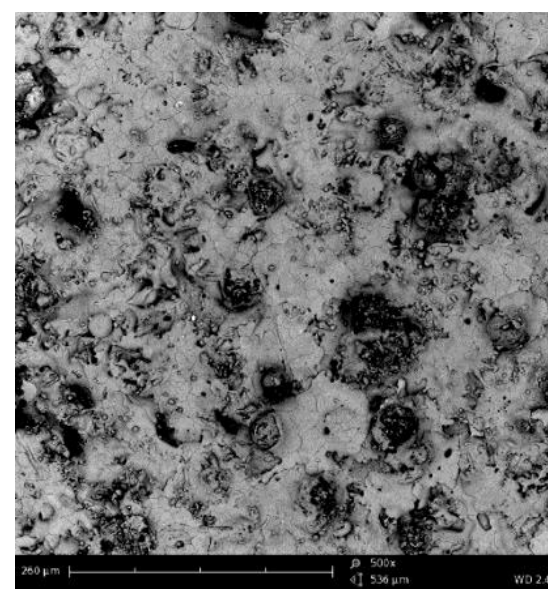

(c)

Fig. 1. SEM micrographs of coatings topography: a) P-622, b) P-689, c) P-756

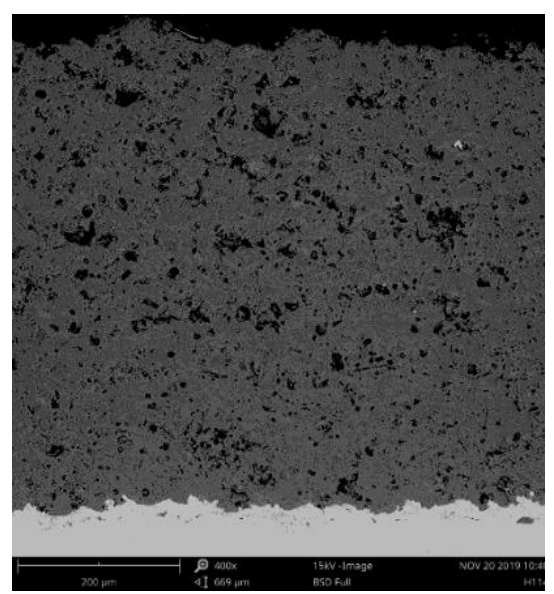

(a)

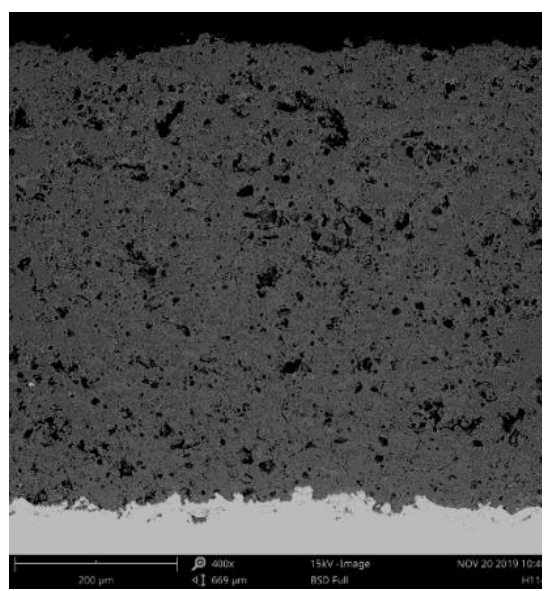

(b)

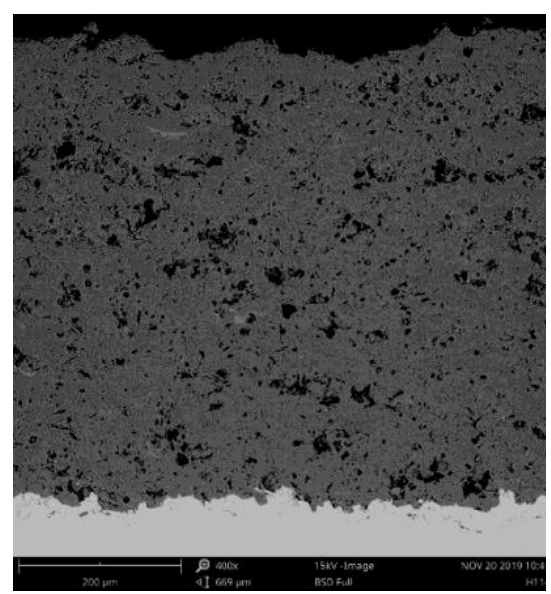

(c)

Fig. 2. SEM micrographs of coatings cross-section: a) P-622, b) P-689, c) P-756 
Microstructures of coatings, observed for samples' cross-sections, revealed that all the coatings had a characteristic lamellar structure, with micropores and single cracks. A homogeneous structure was observed. Similar one was reported in the literature [17:19]. The coatings were well bonded to bond coat layer, additionally the continuity was observed also at the interface between bond coat and substrate. The thickness of the ceramic coating was about $380 \mu \mathrm{m}$, while the bond coat - about $30 \mu \mathrm{m}$.

Investigations of coatings microstructures (Fig. 2) showed the differences in porosity. As the electrical power increased, the porosity decreased. It was caused by more intensive heat, which allowed to melt the powder more effectively. The average porosity values of coatings are given in table III. The porosity level is similar to those reported in $[18,20]$. The small values of standard deviation in obtained results, indicate a compact and homogeneous structure. In the case of microhardness (Tab. III), it was noted that the lower the porosity, the higher the hardness of the coatings. In this case, the electrical power again was of great importance, as it allowed for better melting of powder, which subsequently formed a dense coating with well-fitting lamellas. The microhardness values are typical for this material and manufacturing method $[12,19]$.

Table III. Average values of porosity, microhardness, fracture toughness and adhesion of the sprayed coatings

\begin{tabular}{ccccc}
\hline $\begin{array}{c}\text { Sample } \\
\text { code }\end{array}$ & $\begin{array}{c}\text { Porosity, } \\
\text { vol. } \%\end{array}$ & $\begin{array}{c}\text { Microhardness, } \\
\text { HV0.1 }\end{array}$ & $\begin{array}{c}\text { Fracture } \\
\text { toughness, MPa } \\
\mathbf{m}^{\mathbf{1 / 2}}\end{array}$ & $\begin{array}{c}\text { Adhesion bond } \\
\text { strength, MPa }\end{array}$ \\
\hline P-622 & $8.9 \pm 0.7$ & $925 \pm 93$ & $3.74 \pm 0.25$ & $17.4 \pm 2.8$ \\
P-689 & $6.7 \pm 0.5$ & $977 \pm 85$ & $3.53 \pm 0.21$ & $20.3 \pm 3.4$ \\
P-756 & $5.2 \pm 0.5$ & $1048 \pm 89$ & $3.27 \pm 0.24$ & $24.6 \pm 3.9$ \\
\hline
\end{tabular}

When analyzing the values of fracture toughness (Tab. III) and microhardness, an inversely proportional relationship was observed. Harder coatings, as suspected, were of lower facture toughness. Values of Kc may be different, depending on the adopted estimation model (more than 20 can be found in the literature), as well as the Vickers' indenter loading [18,21]. The values of Kc collected in table III are similar, which suggests that the process parameters did not affect Kc.

The adhesion of coatings determined according to the standardized pull-off test showed a clear dependence on the electrical power. The use of a bond coat layer has improved adhesion. Without a Ni-Cr coating, the adhesion of the $\mathrm{Al}_{2} \mathrm{O}_{3}+\mathrm{TiO}_{2}$ layer reached a maximum of $14 \mathrm{MPa}$. As showed in table III, these values are higher up to several dozen $\%$. Similar values were achieved in works $[22,23]$. The obtained fracture revealed mixed topography, with a significant proportion of adhesive one (over $80 \%$ ).

The values of the volumetric wear coefficients of the tested coatings are shown in figure 3. A clear tendency to improve wear resistance with the increased electric power of the plasma arc was observed. This results in better melting of powder particles and a more compact structure. The similar intensity of wear were reported in $[24,25]$. The values of friction coefficients were around 0.58 and no dependence on process parameters was noticed.

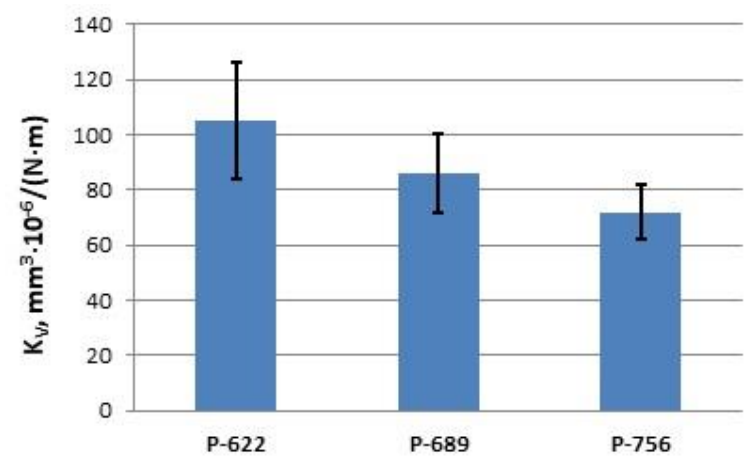

Fig. 3. Average intensity of wear of sprayed coatings

Figure 4 shows exemplary wear trace of the sprayed coating. Non-homogeneous surface with ploughing was observed. Some particles, that were not well bonded, were easily removed from the surface of the coating. However, some of them remained between the ball and the coating and were pressed into wear trace (plastic deformation) [26]. Moreover, numerous micro-scratches at various depths were observed. The worn surface was uneven, which indicated that parts of the coating were pulled out during the test. The 
predominant mechanism of wear was adhesive wear, which is consistent with the observations of other authors $[27,28]$.

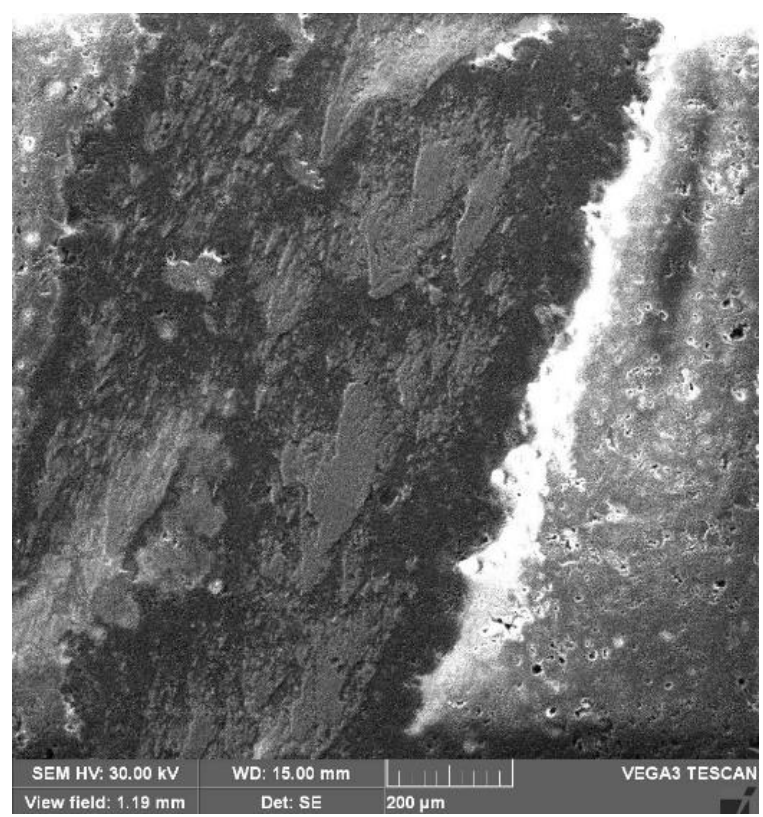

Fig. 4. Example of wear trace in the P-756 coating

Wear resistance of coatings was related both to their basic mechanical properties such as microhardness and fracture toughness, as well as with the microstructure, adhesion and porosity of the coatings [29,30]. The experimental relationship between wear intensity and mechanical properties (hardness and fracture toughness) was proposed in [31]. Figure 5 shows the results of the abovementioned relationship in the reference to the coatings investigated in this article. It was observed that, when taking porosity into account, this relationship has an even higher value of the correlation coefficient $\mathrm{R}^{2}$.

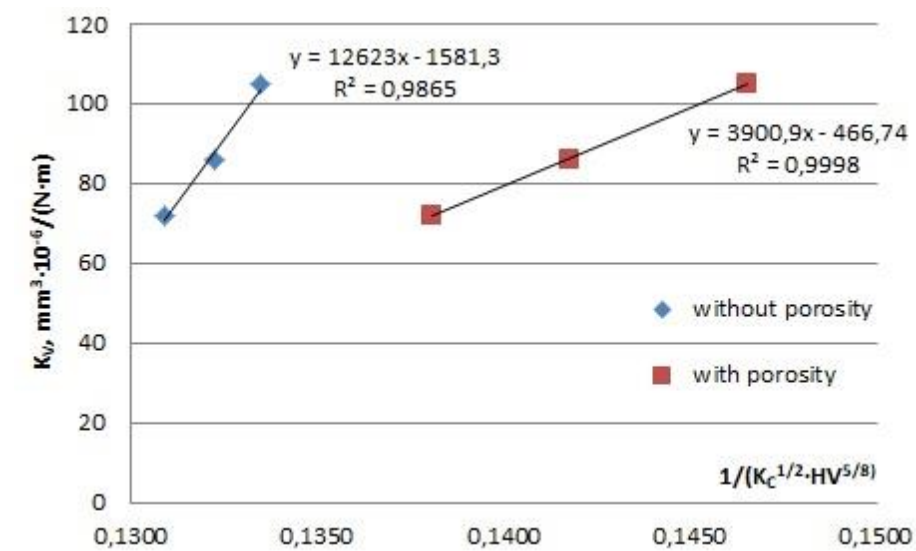

Fig. 5. Relationship between mechanical properties and intensity of wear of the deposited coatings

\section{Conclusions}

In the article $\mathrm{Al}_{2} \mathrm{O}_{3}+13 \mathrm{wt} \% \mathrm{TiO}_{2}$ coatings were manufactured by APS method on the stainless steel substrates with $\mathrm{Ni}+20 \mathrm{wt} \% \mathrm{Cr}$ bond coat. The microstructure and morphology were characterized, also porosity, fracture toughness as well as adhesion strength were examined. Additional microhardness measurements and intensity of wear resistance were carried out. The research provided the following conclusions:

- CPSP critical process parameters (in this article the influence of the electrical power of the plasma jet was examined) have a significant impact on the mechanical properties of the manufactured coatings;

- no differences in coatings morphology and microstructure were observed, except the porosity value and slightly differences in the amount of unmolten powder particles (direct observation of the surface topography with SEM);

- greater amount of melted powder particles results in better cohesion in the coating and consequently better wear resistance. 
The future studies will focus on the influence of the plasma enthalpy (mainly type and flow rate of the plasma gases) on microstructure and mechanical properties of manufactured coatings.

Author Contributions: conceptualization J.S. and L.Ł.; methodology L.Ł. and M.M.; investigation J.S., M.M. and A.N.; writing - original draft preparation L.E.; writing - review and editing M.M., A.N. and L.Ł.

Funding acquisition: This research received no external funding.

Conflicts of Interest: The authors declare no conflict of interest.

\section{References}

[1] Pawłowski L., The Science and Engineering of Thermal Spray Coatings, 2nd ed., Wiley: Chichester, 2008, ISBN 978-0471-49049-4.

[2] Maruszczyk A., Dudek A., Szala M., Research into Morphology and Properties of TiO2 - NiAl Atmospheric Plasma Sprayed Coating. Adv. Sci. Technol. Res. J., 2017, Vol. 11(3), 204-210. https://doi.org/10.12913/22998624/76450

[3] Góral A., Źórawski W., Charakterystyka mikrostruktury powłok Ni-Al2O3 natryskanych zimnym gazem. Welding Technology Review, 2015, Vol. 87(9), 34-37. https://doi.org/10.26628/wtr.v87i9.448

[4] Szala M., Hejwowski T., Cavitation Erosion Resistance and Wear Mechanism Model of Flame-Sprayed Al2O340\%TiO2/NiMoAl Cermet Coatings. Coatings, 2018, Vol. 8(7), 254. https://doi.org/10.3390/coatings8070254

[5] Aliofkhazraei M., Anti-Abrasive Nanocoatings: Current and Future Applications, Elsevier, 2014, ISBN 978-0-85709217-5.

[6] Sert Y., Toplan N., Tribological behavior of a plasma-sprayed Al2O3-TiO2-Cr2O3 coating. Materials and Technology, 2013, Vol. 47(2), 181-183. [Hyperlink]

[7] Wang Y.M., Tian H., Shen X.E., Wen L., Ouyang J.H., Zhou Y., Jia D.C., Guo L.X., An elevated temperature infrared emissivity ceramic coating formed on 2024 aluminium alloy by microarc oxidation. Ceramics International, 2013, Vol. 39(3), 2869-2875. https://doi.org/10.1016/j.ceramint.2012.09.060

[8] Wang M., Shaw L.L., Effects of the powder manufacturing method on microstructure and wear performance of plasma sprayed alumina-titania coatings. Surface and Coatings Technology, 2007 Vol. 202(1), 34-44. https://doi.org/10.1016/j.surfcoat.2007.04.057

[9] Aruna S.T., Balaji N., Shedthi J., Grips V.K.W., Effect of critical plasma spray parameters on the microstructure, microhardness and wear and corrosion resistance of plasma sprayed alumina coatings. Surface and Coatings Technology, 2012, Vol. 208(15), 92-100. https://doi.org/10.1016/j.surfcoat.2012.08.016

[10] Ibrahim A., Hamdy A.S., Microstructure, Corrosion, and Fatigue Properties of Alumina-Titania Nanostructured Coatings. Journal of Surface Engineered Materials and Advanced Technology, 2011, Vol. 1(3), 101-106. DOI:10.4236/jsemat.2011.13015

[11] Geaman V., Pop M.A., Motoc D.L., Radomir I., Tribological properties of thermal spray coatings. European Scientific Journal, ESJ 2014, Vol. 9(10), 154-159. https://doi.org/10.19044/esj.2013.v9n10p\%25p

[12] Yugeswaran S., Selvarajan V., Vijay M., Ananthapadmanabhan P.V., Sreekumar K.P., Influence of critical plasma spraying parameter (CPSP) on plasma sprayed Alumina-Titania composite coatings. Ceramics International, 2010, Vol. 36(1), 141-149. https://doi.org/10.1016/j.ceramint.2009.07.012

[13] Michalak M., Łatka L., Sokołowski P., Porównanie właściwości mechanicznych powłok natryskiwanych plazmowo proszkowo i z zawiesin. Welding Technology Review, 2017, Vol. 89(10), 56-60. https://doi.org/10.26628/wtr.v89i10.819

[14] Chantikul P., Anstis G.R., Lawn B.R., Marshall D.B., A Critical Evaluation of Indentation Techniques for Measuring Fracture Toughness: II, Strength Method. Journal of the American Ceramic Society, 1981, Vol. 64(9), 539543. https://doi.org/10.1111/j.1151-2916.1981.tb10321.x

[15] Lancaster J.K., The influence of substrate hardness on the formation and endurance of molybdenum disulphide films. Wear, 1967, Vol. 10(2), 103-117. DOI:10.1016/0043-1648(67)90082-8.

[16] Vijay M., Selvarajan V., Yugeswaran S., Ananthapadmanabhan P.V., Sreekumar K.P., Effect of Spraying Parameters on Deposition Efficiency and Wear Behavior of Plasma Sprayed Alumina-Titania Composite Coatings. Plasma Sci. Technol., 2009, Vol. 11(6), 666-673. DOI: 10.1088/1009-0630/11/6/07

[17] Djendel M., Allaoui O., Boubaaya R., Characterization of Alumina-Titania Coatings Produced by Atmospheric Plasma Spraying on 304 SS Steel. Acta Physica Polonica A, 2017, Vol. 132(3), 538-540. doi:10.12693/APhysPolA.132.538; [ [Hyperlink]

[18] Jafarzadeh K., Valefi Z., Ghavidel B., The effect of plasma spray parameters on the cavitation erosion of Al2O3TiO2 coatings. Surface and Coatings Technology, 2010, Vol. 205(7), 1850-1855.

https://doi.org/10.1016/j.surfcoat.2010.08.044 
[19] Wahab J.A., Ghazali M.J., Baharin A.F.S., Microstructure and mechanical properties of plasma sprayed Al2O3 13\%TiO2 Ceramic Coating. MATEC Web Conf. 2017, 87, 02027. doi:10.1051/matecconf/20178702027

[20] Yilmaz R., Kurt A.O., Demir A., Tatlı Z., Effects of TiO2 on the mechanical properties of the Al2O3-TiO2 plasma sprayed coating. Journal of the European Ceramic Society, 2007, Vol. 27(2-3), 1319-1323. https://doi.org/10.1016/j.jeurceramsoc.2006.04.099

[21] Łatka L., Niemiec A., Michalak M., Sokołowski P., Tribological properties of Al2O3+ TiO2 coatings manufactured by plasma spraying. Tribology, 2019,Vol. 283(1), 19-24. doi:10.5604/01.3001.0013.1431

[22] Zhang J., He J., Dong Y., Li X., Yan D., Microstructure and properties of Al2O3-13\%TiO2 coatings sprayed using nanostructured powders. Rare Metals, 2007, Vol. 26(4), 391-397. https://doi.org/10.1016/S1001-0521(07)60234-4

[23] Jordan E.H., Gell M., Sohn Y.H., Goberman D., Shaw L., Jiang S., Wang M., Xiao T.D., Wang Y., Strutt P., Fabrication and evaluation of plasma sprayed nanostructured alumina-titania coatings with superior properties. Materials Science and Engineering: A, 2001, Vol. 301(1), 80-89. https://doi.org/10.1016/S0921-5093(00)01382-4

[24] Ghazali M.J., Forghani S.M., Hassanuddin N., Muchtar A., Daud A.R., Comparative wear study of plasma sprayed $\mathrm{TiO} 2$ and $\mathrm{Al} 2 \mathrm{O} 3-\mathrm{TiO} 2$ on mild steels. Tribology International, 2016, Vol. 93, B, $681-686$. https://doi.org/10.1016/j.triboint.2015.05.001

[25] Łatka L., Michalak M., Jonda E., Atmospheric Plasma Spraying of Al2O3 + 13\% TiO2 Coatings Using External and Internal Injection System. Advances in Materials Science, 2019, Vol. 19(4), 5-17. https://doi.org/10.2478/adms-2019$\underline{0018}$

[26] Żórawski W., Góral A., Makrenek M., Zimowski S., Tribological properties of plasma sprayed Al2O3-13TiO2 nanostructured coatings. Tribologia, 2017, 2, 157-165. [Hyperlilnk]

[27] Çelik I., Structure and surface properties of Al2O3-TiO2 ceramic coated AZ31 magnesium alloy. Ceramics International, 2016, Vol. 42(12), 13659-13663. https://doi.org/10.1016/j.ceramint.2016.05.162

[28] Mehar S., Sapate S.G., Vashishtha N., Bagde P., Effect of Y2O3 addition on tribological properties of plasma sprayed Al2O3-13\% TiO2 coating. Ceramics International, 2020, Vol. 46(8), B, 11799-11810. https://doi.org/10.1016/j.ceramint.2020.01.214

[29] Normand B., Fervel V., Coddet C., Nikitine V., Tribological properties of plasma sprayed alumina-titania coatings: role and control of the microstructure. Surface and Coatings Technology, 2000, Vol. 123(2-3), $278-287$. https://doi.org/10.1016/S0257-8972(99)00532-0

[30] Wang Y., Jiang S., Wang M., Wang S., Xiao T.D., Strutt P.R., Abrasive wear characteristics of plasma sprayed nanostructured alumina/titania coatings. Wear, 2000, Vol. 237(2), 176-185. https://doi.org/10.1016/S00431648(99)00323-3

[31] Rigney D.A., Division A.S. for M.M.S., AIME, M.S. of Fundamentals of friction and wear of materials: papers presented at the 1980 ASM Materials Science Seminar, 4-5 October 1980, Pittsburgh, Pennsylvania, American Society for Metals, 1981, ISBN 978-0-87170-115-2.

(C) 2020 by the authors. Submitted for possible open access publication under the terms and conditions of the Creative Commons Attribution (CC BY) license (http://creativecommons.org/licenses/by/4.0/). 